\title{
Characteristics of fault zones and their control on remaining oil distribution at the fault edge: a case study from the northern Xingshugang Anticline in the Daqing Oilfield, China
}

\author{
Xiao-Fei Fu ${ }^{1,2,3,4} \cdot$ Xiao Lan ${ }^{1,4} \cdot$ Ling-Dong Meng ${ }^{1,2,3,4} \cdot$ Hai-Xue Wang ${ }^{1,2,3,4}$. \\ Zong-Bao Liu ${ }^{1,2,3,4} \cdot$ Zhi-Qiang Guo $^{5} \cdot$ Zai-He Chen ${ }^{5}$
}

Received: 17 September 2015/Published online: 10 August 2016

(C) The Author(s) 2016. This article is published with open access at Springerlink.com

\begin{abstract}
Most major oil zones in the Daqing Oilfield have reached a later, high water cut stage, but oil recovery is still only approximately $35 \%$, and $50 \%$ of reserves remain to be recovered. The remaining oil is primarily distributed at the edge of faults, in poor sand bodies, and in insufficiently injected and produced areas. Therefore, the edge of faults is a major target for remaining oil enrichment and potential tapping. Based on the dynamic change of production from development wells determined by the injection-recovery relationship at the edge of faults, we analyzed the control of structural features of faults on remaining oil enrichment at the edge. Our results show that the macroscopic structural features and their geometric relationship with sand bodies controlled remaining oil enrichment zones like the edges of NNE-striking faults, the footwalls of antithetic faults, the hard linkage segments (two faults had linked together with each other to form a bigger through-going
\end{abstract}

Xiao-Fei Fu

fuxiaofei2008@sohu.com

1 Laboratory of CNPC Fault Controlling Reservoir, Northeast Petroleum University, Daqing 163318, Heilongjiang, China

2 Science and Technology Innovation Team in Heilongjiang Province "Fault Deformation, Sealing and Fluid Migration", Daqing 163318, Heilongjiang, China

3 The State Key Laboratory Base of Unconventional Oil and Gas Accumulation and Exploitation, Earth Science College, Northeast Petroleum University,

Daqing 163318, Heilongiiang, China

4 Earth Science College, Northeast Petroleum University, Daqing 163318, Heilongjiang, China

5 NO. 5 Production Plant, Huabei Oilfield Co., PetroChina, Xinji 052360, Hebei, China

Edited by Jie Hao fault), the tips of faults, and the oblique anticlines of soft linkages. Fault edges formed two types of forward microamplitude structures: (1) the tilted uplift of footwalls controlled by inverse fault sections and (2) the hanging-wall horizontal anticlines controlled by synthetic fault points. The remaining oil distribution was controlled by microamplitude structures. Consequently, such zones as the tilted uplift of the footwall of the NNW-striking antithetic faults with a fault throw larger than $40 \mathrm{~m}$, the hard linkage segments, the tips of faults, and the oblique anticlines of soft linkage were favorable for tapping the remaining oil potential. Multi-target directional drilling was used for remaining oil development at fault edges. Reasonable fault spacing was determined on the basis of fault combinations and width of the shattered zone. Well core and log data revealed that the width of the shattered zone on the side of the fault core was less than $15 \mathrm{~m}$ in general; therefore, the distance from a fault to the development target should be larger than $15 \mathrm{~m}$. Vertically segmented growth faults should take the separation of the lateral overlap of faults into account. Therefore, the safe distance of remaining oil well deployment at the fault edge should be larger than the sum of the width of shattered zone in faults and the separation of growth faults by vertical segmentation.

Keywords Fault edge - Fault zone structure · Segmentation growth · Micro-amplitude structure . Sealing $\cdot$ Safety distance

\section{Introduction}

About one-third of major onshore oilfields in East China are complexly faulted, and characterized by high water cut, high recovery percentage, high recovery rate, low reserve/ 
production ratio, and low oil recovery ratio (Yu 1998; Hu 2008; Jin et al. 2009). After long-term waterflooding, most of them are at the later stage of high waterflooding. However, the oil recovery is only $35 \%$ or so, and approximately $50 \%$ of reserves remain to be recovered. At the stage of high water cut and high recovery percentage of China National Petroleum Corporation (CNPC), annual oil production had accounted for $58 \%$ of total oil production, and remaining recoverable reserves had reached $44 \%$ of cumulative remaining recoverable reserves until the end of 2011 (Han 2010; Liu et al. 2008). The core of development and adjustment of old oilfields during the high water cut stage is "recognizing and recovering remaining oil," yet the remaining oil in fault oilfields concentrates at the edges of faults and poor sand bodies, as well as insufficiently injected and produced areas; therefore, the edges of faults are a major target for remaining oil enrichment and potential tapping (Jiang 2013). Currently, domestic and foreign research on remaining oil at fault edges of fault oilfields mainly focuses on reservoir heterogeneity, well pattern rationality, microscopic displacement experiments, potential tapping methods, etc. (Miall 1994; Peng et al. 2007; Yue et al. 2008; Hou et al. 2014; Feng et al. 2014), seriously neglecting the influence of fault zone structural features on remaining formation, enrichment, and development (Jin et al. 2012). This influence is manifest in two aspects. The first is the different sites of remaining oil owing to the configuration of faults and formation occurrence (Qi 2004), fault combination pattern, fault linkage status (hard linkage, soft linkage, cross linkage, superimposed deformation, etc.) (Kim and Sanderson 2005), and associated micro-amplitude structural differences. The foundation of research into remaining oil at the fault edges is to examine the microscopic combinations, linkages, and associated micro-amplitude structural features of faults. The second aspect is that the remaining oil at the fault edges is affected by fault sealing (Yielding 2002), apart from its relevance to the injection-recovery relationship, such as water channeling and oil leakage occurring frequently at footwall and hanging wall of faults. Thus, quantitative evaluation of fault sealing is the core of research into remaining oil at fault edges (Bretan et al. 2003; Fu et al. 2010; Liu et al. 2014). In this paper, the Putaohua oil layer of the Xingbei Oilfield in the Daqing Placanticline was selected for the study of faults and remaining oil. According to the dynamic variation of production from development wells controlled by fault edge injection-recovery relationships, the control of fault zone structural features on remaining oil at the fault edge was analyzed, and a systematic approach for predicting the remaining oil distribution at fault edges of fault oilfields during the high water cut stage was established.

\section{Geological setting}

The Songliao Basin is a typical rift basin (Gao 1980, 1983; Hu and Wang 1996; Zhang et al. 1996). There are three structural evolution stages of the basin including fault depression $\left(\mathrm{K}_{1} h-\mathrm{K}_{1} y c h\right)$, depression $\left(\mathrm{K}_{1} d-\mathrm{K}_{2} n\right)$, and inversion ( $\left.\mathrm{K}_{2} m-\mathrm{Q}\right)$ (Gao and Cai 1997; Yun et al. 2002). The Daqing Placanticline is a large anticlinal zone located in the central depression of the Songliao Basin (Fig. 1), composed of seven anticlines (Lamdian, Sartu, Xingshugang, Gaotaizi, Taipingtun, Putaohua, and Aobaota), which are mostly asymmetrical with gentle eastern flanks and steep western flanks. The Daqing Placanticline is located in the two oil generation areas of the Qijia-Gulong and Sanzhao Depressions, and formed a world-class oil field (Gao and Cai 1997). The first member of the Yaojia Formation is characterized as an interbedded sandstonemudstone reservoir and is the major oil reservoir of the Daqing Placanticline (Fig. 2).

The Xingshugang Anticline is a secondary structure within the Daqing Placanticline, and the study area is located at the north of the anticline (Fig. 1). 42 tensor-shear faults developed here (Sun et al. 2013), dominantly NWNNW striking and NE dipping, though a minority of them are NW dipping. Fault throw is usually less than $50 \mathrm{~m}$, and extension is generally less than $4 \mathrm{~km}$. More than 4000 development wells have been drilled in the area. At present, the water cut is $93 \%$ and tapping the potential of remaining oil at the fault edges is essential to increase production.

\section{Control of fault zone features on remaining oil distribution}

Fault zone features primarily refer to the occurrence, combinations, linkage status, and associated micro-amplitude structural features (Fu et al. 2011) of fault zones, which affect fault edge injection-recovery relationships and thereby control remaining oil distribution.

\subsection{Fault-reservoir configuration and different remaining oil distribution in the footwall and hanging wall}

It is found by comparing development well productivity of parts of Fault F234 with different strikes that the development wells at edge of NNW-striking faults have higher productivity (Fig. 3) and richer remaining oil. At the first member of the Yaojia Formation in the Daqing Placanticline, the sedimentary system is fluvial-deltaic facies, source direction is from the north (Liu 2008; Liu 2010), 


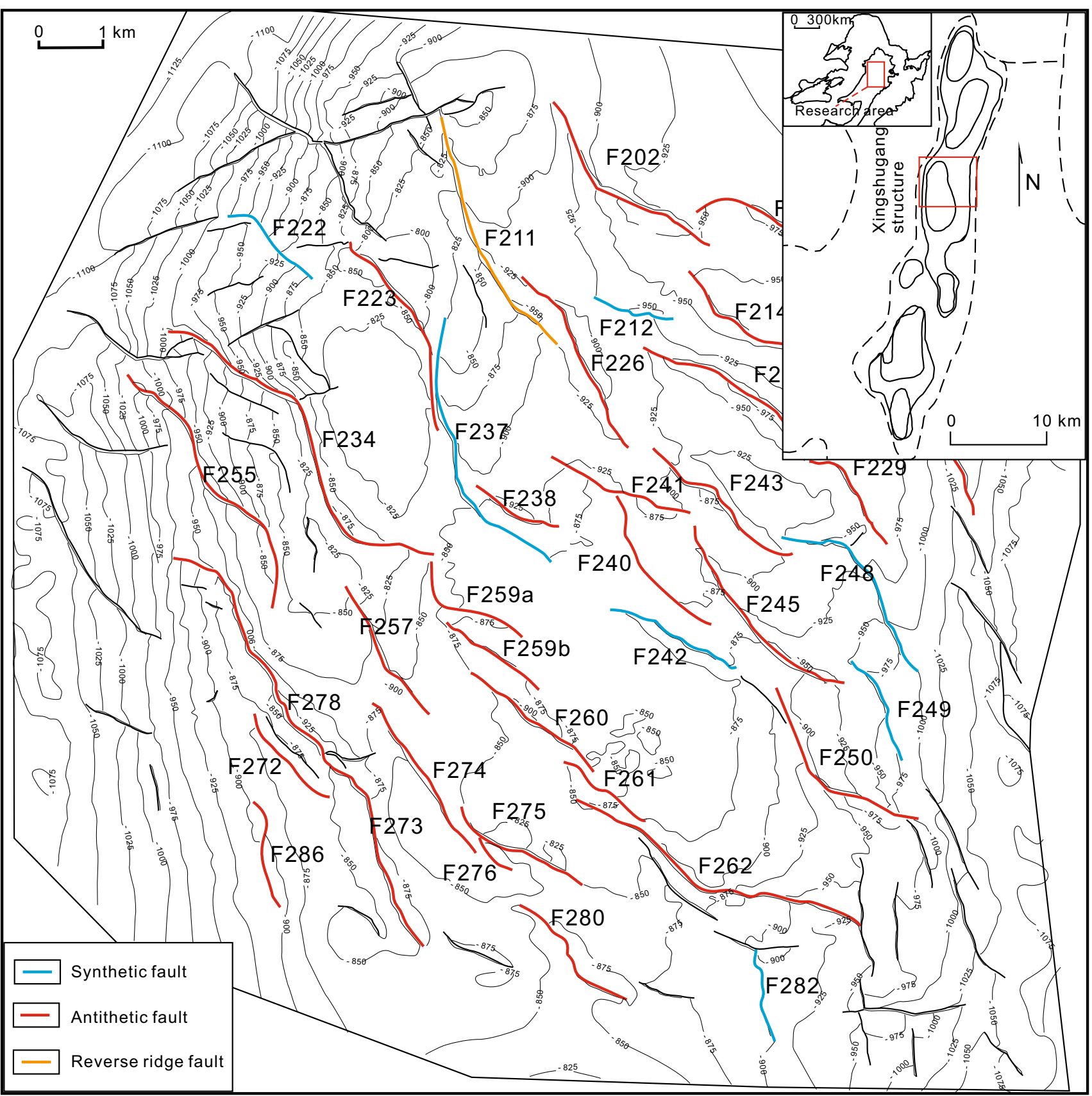

Fig. 1 Location and fault distribution of the study area

and channel sand is the major reservoir body. The channels have an approximately $\mathrm{N}$-striking to NE-striking distribution and intersect NW-striking faults at high angles. Faults commonly form the enrichment boundary of remaining oil. Remaining oil tends to be found easily due to incomplete injection and recovery. At fault segments of the same trend, the larger the throw is, the higher the intensity of daily production gets. Remaining oil is the richest (Fig. 3) as the throw reaches the limit value. The limit value of throw of remaining oil enrichment at Fault F234 is between 56 and $68 \mathrm{~m}$, while that of Fault F259-F262 is from 42 to $60 \mathrm{~m}$.
The greater the fault throw, the richer the remaining oil, which is controlled by the two factors. One is that the oil layer in the first member of Yaojia Formation tends to be juxtaposed against an upper mudstone, so that the sealing capacity of faults becomes stronger with larger fault throw. The other one is that due to differential subsidence, the areas with greater throw of antithetic faulting and those that are closer to the structural high are more conducive to the enrichment of remaining oil, resulting in greater daily production. Faults could be classified into four types in light of fault-reservoir configurations (Cloos 1928; Hills 


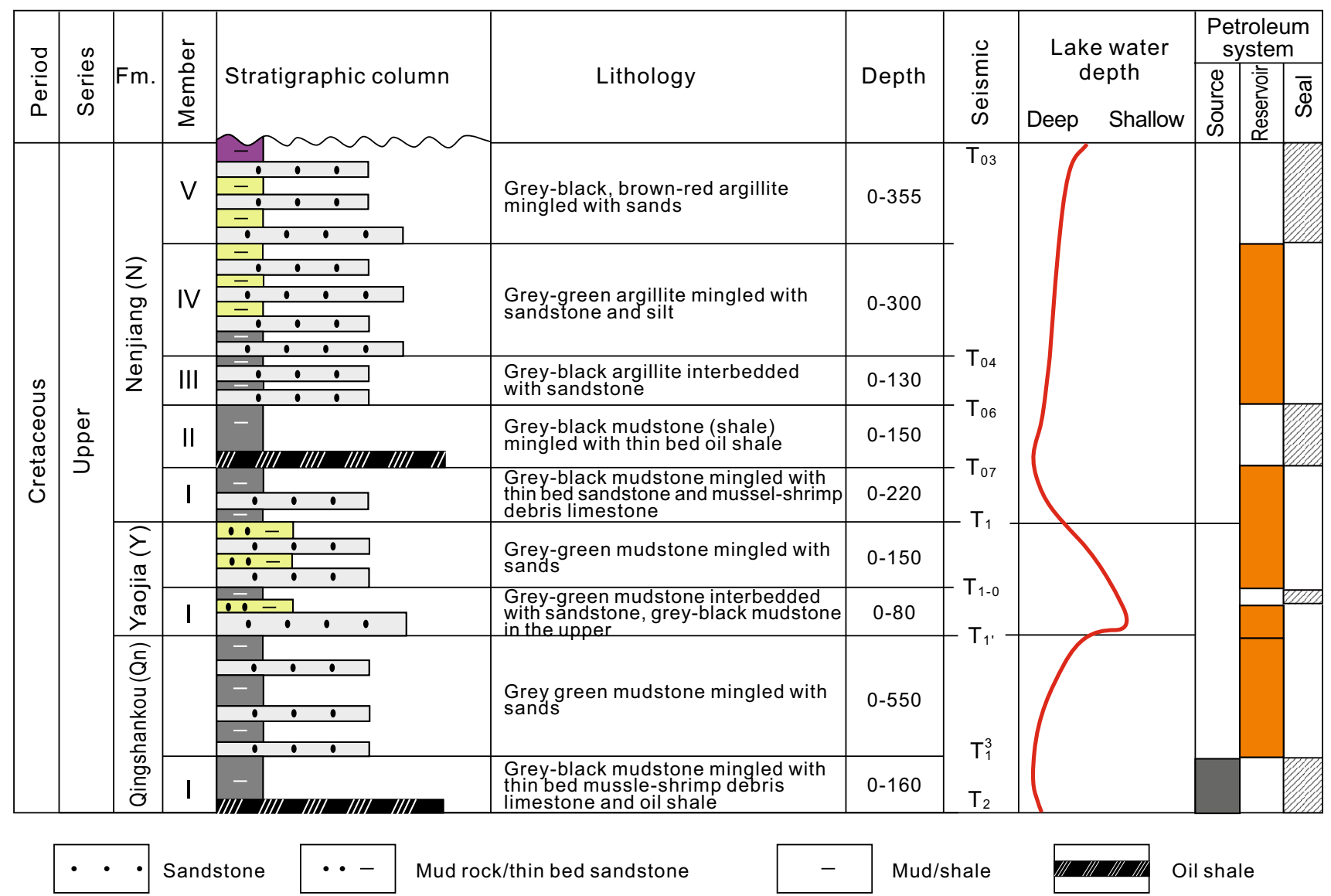

Fig. 2 Correlation map of strata hydrocarbon generation-storage-cover combinations in the Northern Songliao Basin

1953; Peacock et al. 2000; Qi 2004): antithetic faults, synthetic faults, ridge-like faults, and anti-ridge-like faults. In the Putaohua oil layer, antithetic faults (33) and synthetic faults (8) mainly developed. According to the dynamic data of fault edge development wells in the footwalls and hanging walls (Fig. 3), remaining oil is richer in the hanging walls of antithetic faults.

\subsection{Fault linkage status identification and remaining oil distribution}

It is universally observed that faults grow by segmentation in rift basins (Peacock 1991; Kim and Sanderson 2005; Wang et al. 2013), and the fault displacement-distance curve is one of the essential and most widely used approaches to identify segmented faulting. Displacement occurs in the low-value zone, i.e., the faults grow by segmentation (Peacock and Sanderson 1994, 1991; Fossen 2010; Fossen et al. 2007; Liu et al. 2012; Giba et al. 2012). Additionally, there are isolated faults. Displacement and throw are linearly related, so the throw-distance curve is applied to quantitatively define the faults that grow by segmentation and the isolated faults. Restricted by poor seismic resolution, it is common that two segmented growth faults are interpreted as one. To effectively reduce uncertainty of fault interpretation, we use an approach derived from the research achievements of Soliva and Benedicto (2004), applying the "relay displacement $(D$, the aggregate displacement measured at the fault overlap center)/separation ( $S$, the vertical distance of fault overlap)" to quantitatively affirm fault growth stages. According to relevant fault data that have been published at home and abroad (Soliva and Benedicto 2004; Soliva et al. 2008), on the basis of 3D seismic data from the Songliao Basin, relay displacement $(D)$ /separation $(S)$ data are tallied, completing the quantitative discrimination criterion for fault segment growth linkage. When $D / S$ is smaller than 0.27 , faults are at the overlap stage or at "soft-linkage" stage. When $D / S$ is between 0.27 and 1 , faults are at a stage of fault initiation, also at the "soft-linkage" stage. When $D /$ $S$ is larger than 1 , faults are totally breached, or at the "hard-linkage" stage. Therefore, fault growth stages can be divided into the overlap, incipiently linked relays, and complete breaching (Wang et al. 2014) stages. For the 41 faults in the Xinbei development zone, comprehensive analysis and correction were conducted for the fault 

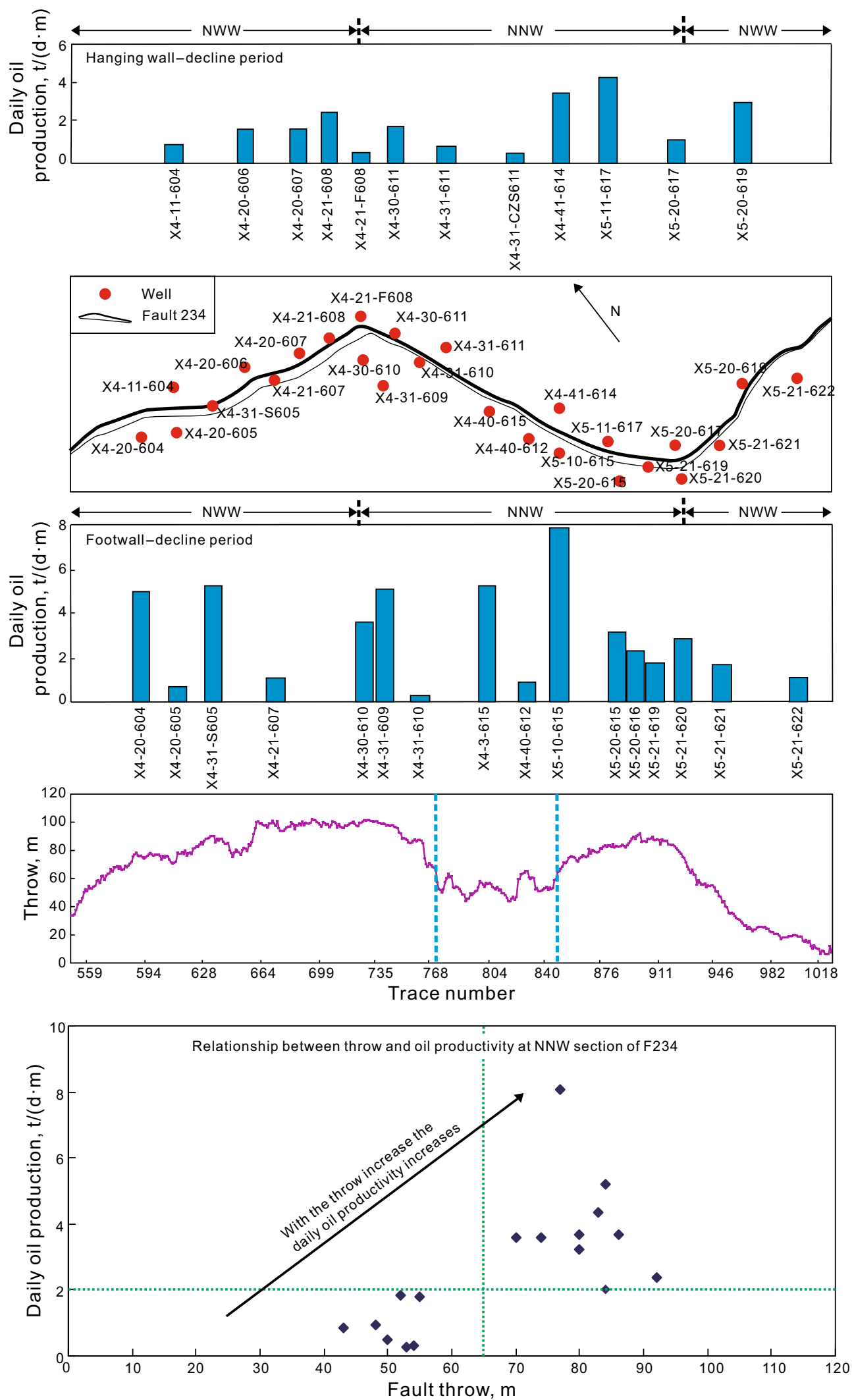

Fig. 3 Relationship between remaining oil distribution and oil productivity and fault throw. Oil production is the amount of oil production by one meter thickness and each day. $t$ represents ton, $d$ represents day, and $m$ is the thickness of oil layer 


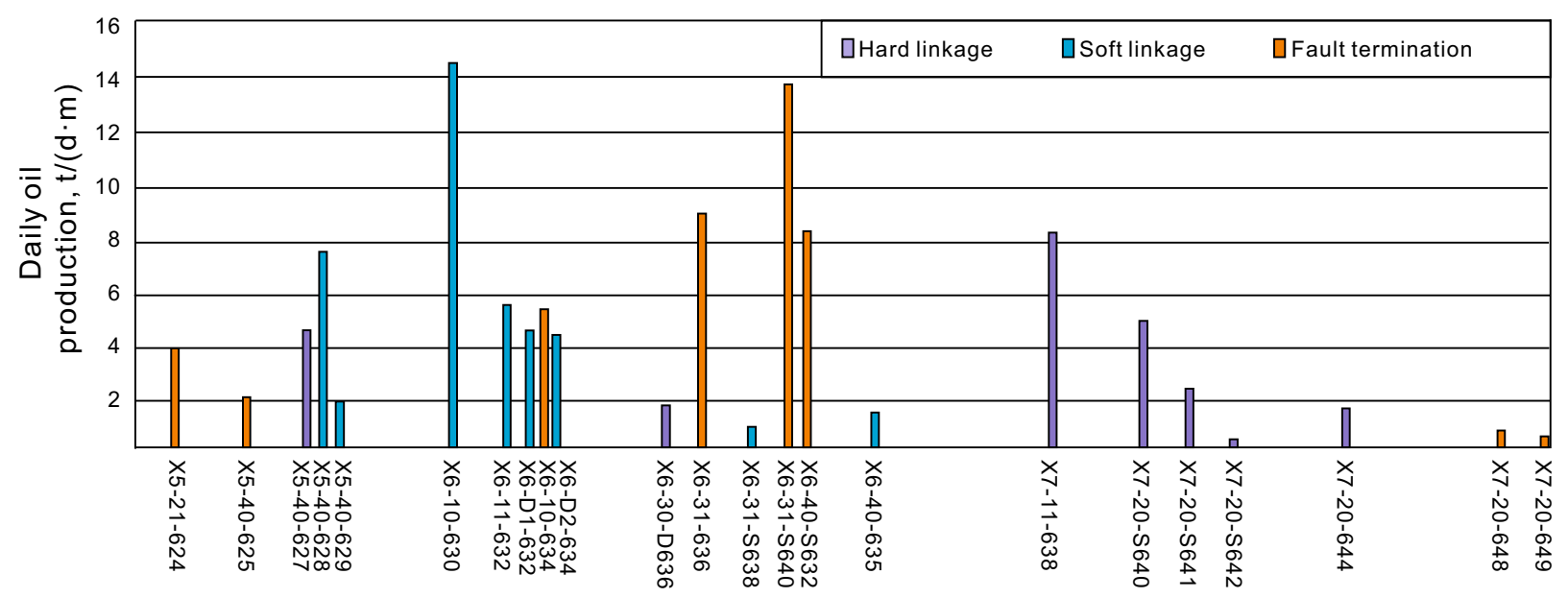

(a) Typical well daily oil production-initial

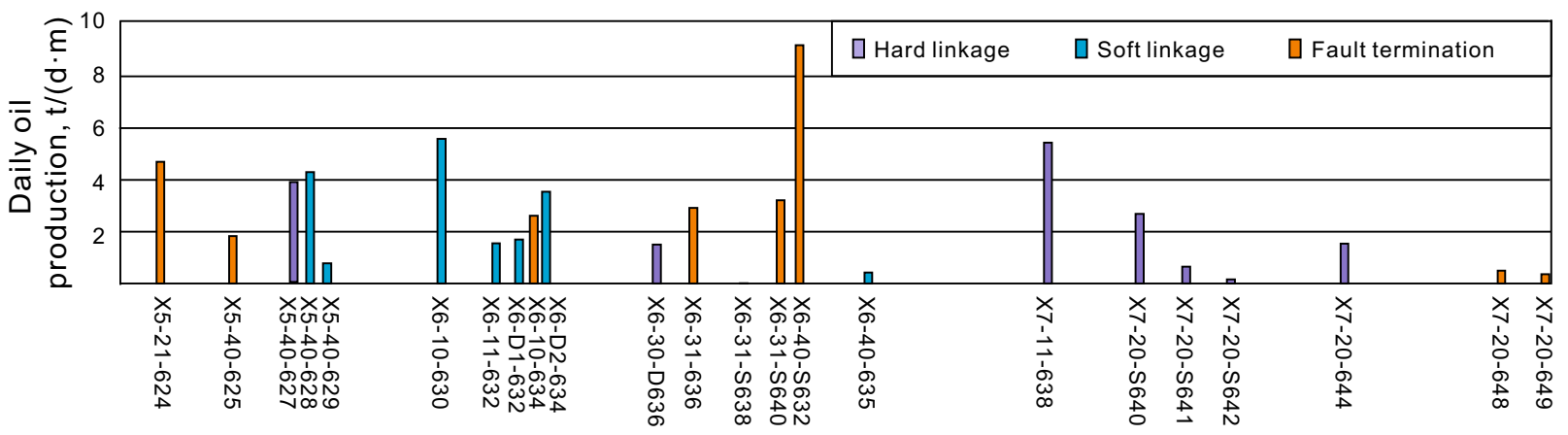

(b) Typical well daily oil production-decline

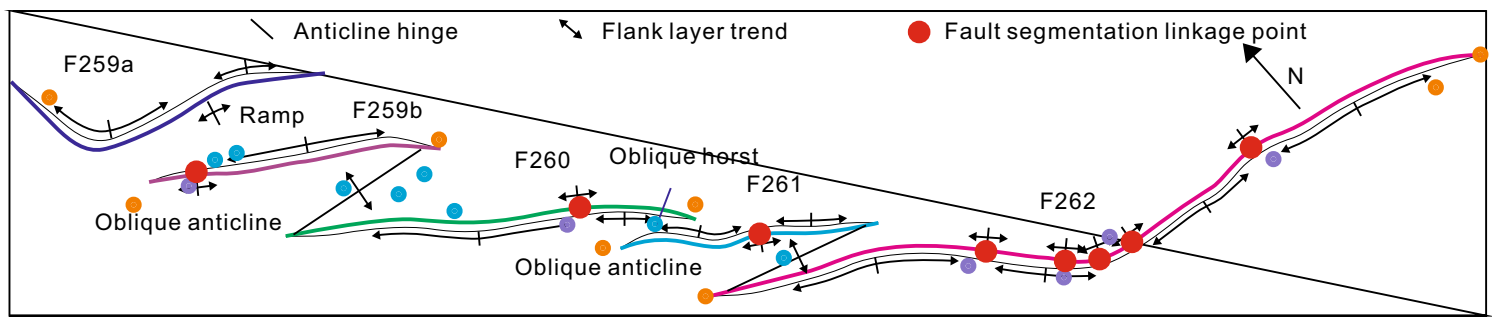

(c) Fault marginal positive micro-amplitude structure

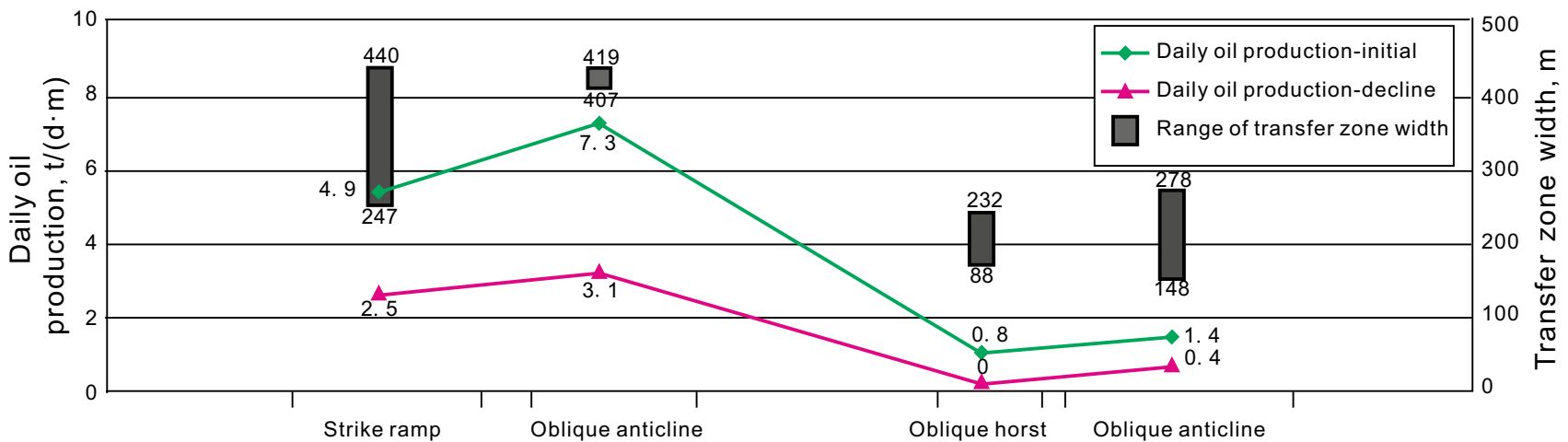

Fig. 4 Remaining oil distribution of different linkage status in the vicinity of faults from oil production data 


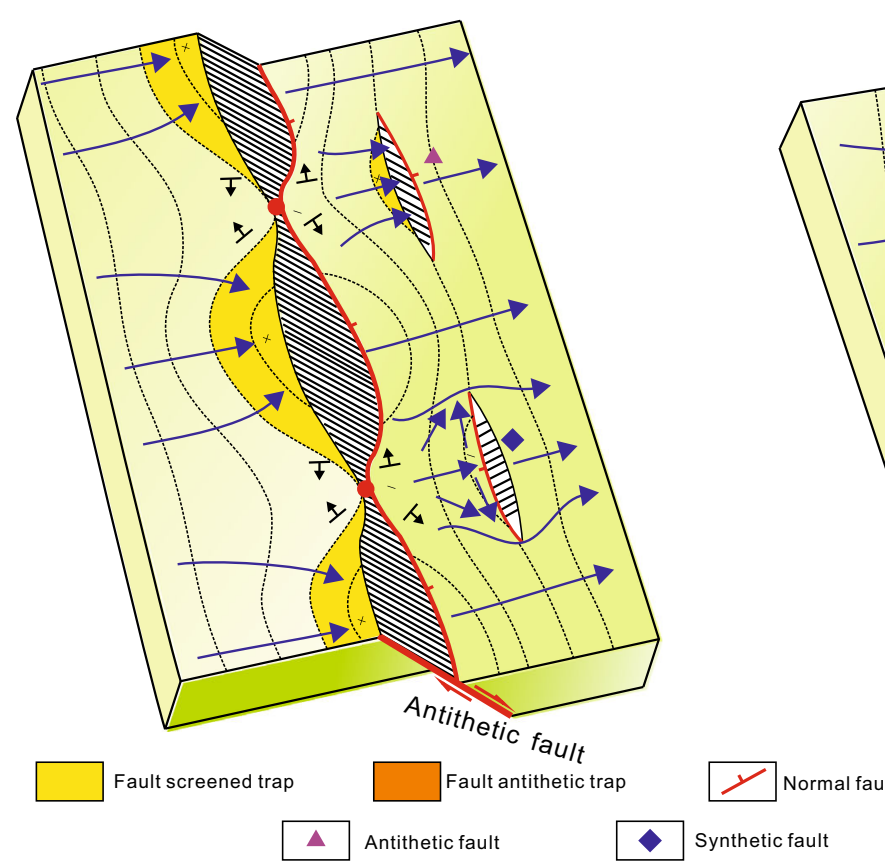

(a) Antithetic fault

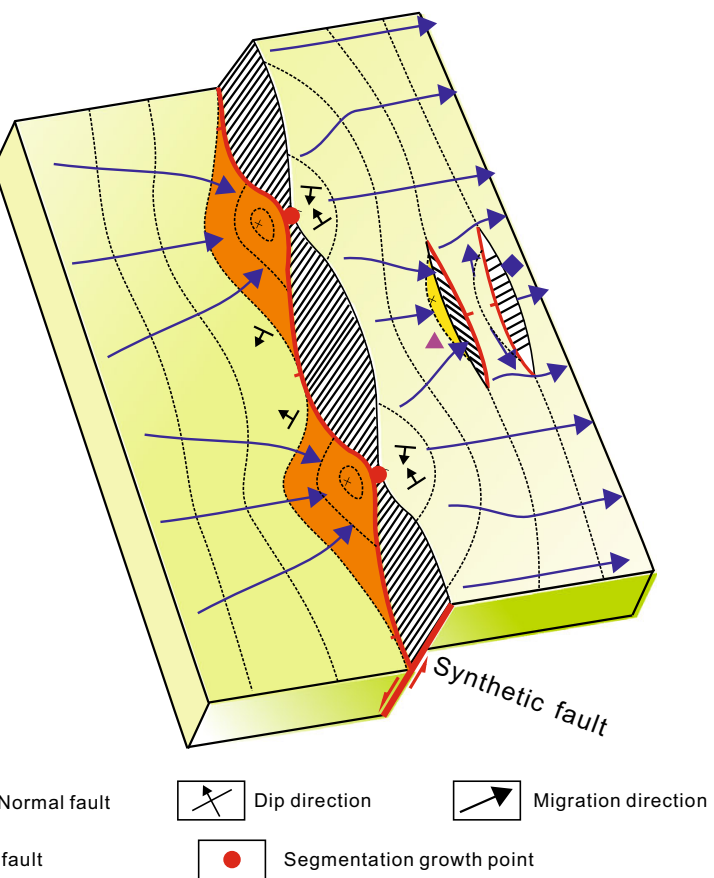

(b) Synthetic fault

Fig. 5 Micro-amplitude structure of antithetic and synthetic faults during segmentation growth

combinations based on the quantitative discrimination criteria mentioned above. Near NNW-striking faults with remaining oil, remaining oil is rich near hard linkages and the end of faults, but it is less near soft linkages (Fig. 4). Structural configurations of soft linkages vary among different fault combinations, including relay ramps, oblique anticlines, and oblique grabens. Remaining oil enrichment in soft-linkage areas has a positive relationship with the width of the transfer zone (Fig. 4). Positive structures developed in the transfer zones of oblique anticlines are richer in remaining oil.

\subsection{Types and remaining oil enrichment of micro- amplitude associated structures}

There are two types of positive micro-amplitude structures developed at the edges of faults (Fig. 5). The first is tilted fault blocks controlled by footwalls of antithetic faults, and the second is lateral anticlines at hanging walls controlled by synthetic fault linkage points. Because of the control of the two types of micro-amplitude structures by the position of fault segmentation points, throw-distance curves can be used for effective identification of micro-amplitude structures. From the 278 antithetic fault throw-distance curves, 7 segmented growth points (Fig. 6) could be identified, where 8 micro-amplitude structures (Fig. 6) developed and some of them are interconnected. By comparing with daily oil production intensity, a large number of positive micro- amplitude structures can be defined scattered throughout the hanging wall of Fault F234, and concentrated in the north and south. It is shown at the early production period that daily oil production of the wells at high positions in positive micro-amplitude structures is much higher than those in nonpositive ones (Fig. 7). Positive micro-amplitude structures are distributed wholly in footwalls, characterized by larger scale, and numerically fewer. Statistics show that daily oil production of the developing wells at high positions in positive micro-amplitude structures to the south is obviously higher than that far away from the positive micro-amplitude structures (Fig. 7). Comprehensive analysis reveals that remaining oil reservoirs in footwalls form more easily than those in hanging walls of antithetic faults. However, for the same fault block, remaining oil is richer in positive micro-amplitude structures developed at the fault edge, which indicates enrichment and distribution of remaining oil.

\section{Internal structures of fault zones and their control on remaining oil distribution}

\subsection{Internal structures of fault zones and their relationship with remaining oil distribution}

Conventional research on internal structure of fault zones is mainly based on outcrop area studies (Caine et al. 1996; 


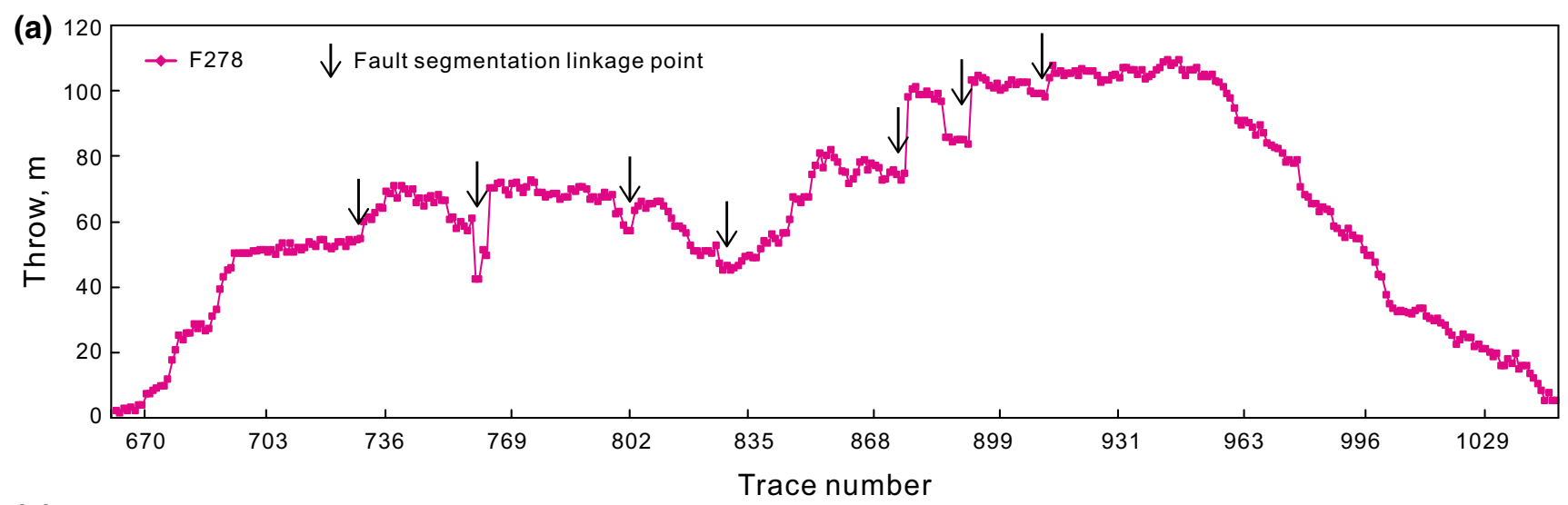

(b)

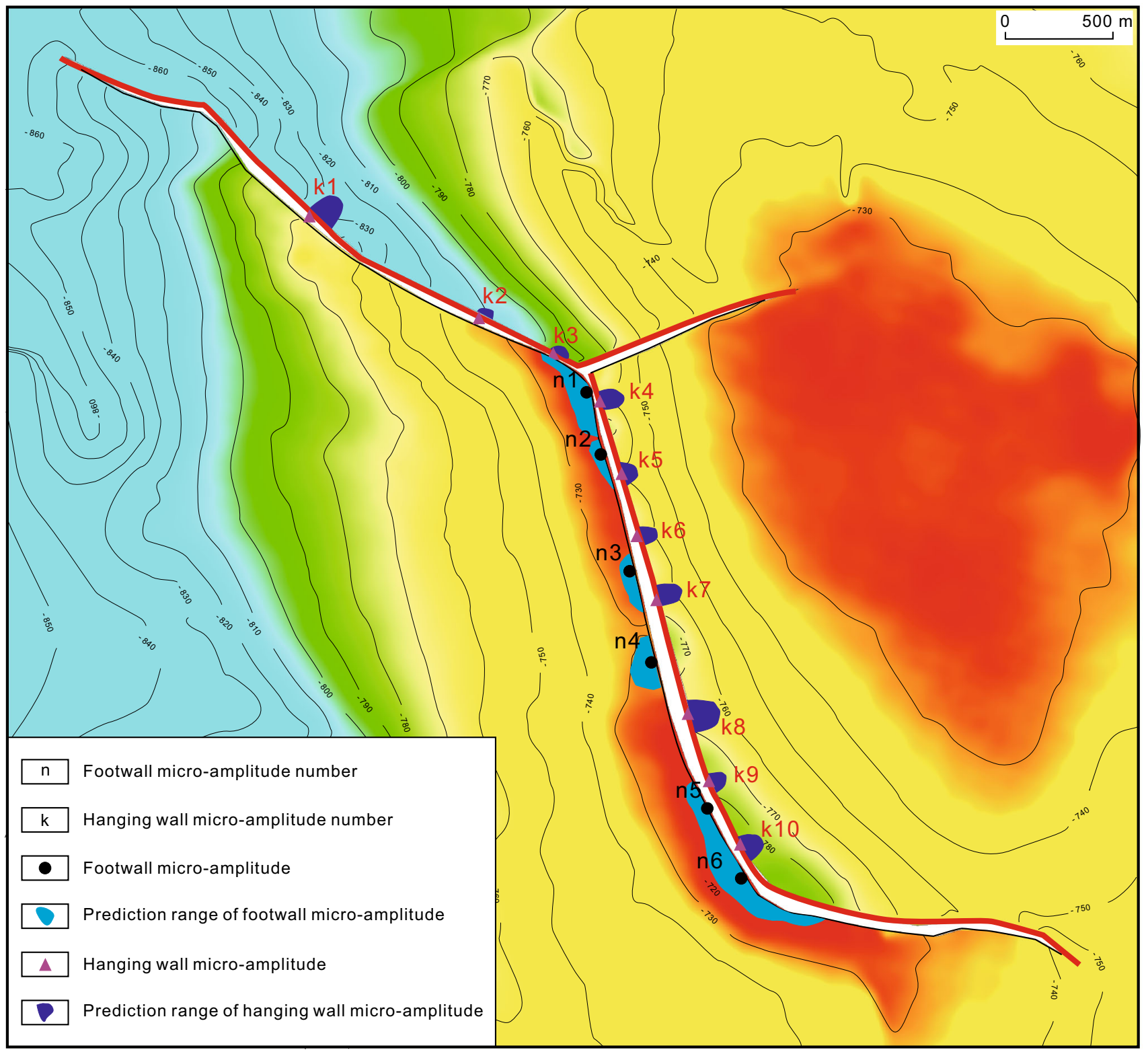

Fig. 6 Throw-distance curve and micro-amplitude structure distribution of No. 278 antithetic fault. a Throw-distance curve of No. 278 antithetic fault and $\mathbf{b}$ relation between fault segmentation and micro-amplitude structure distribution 

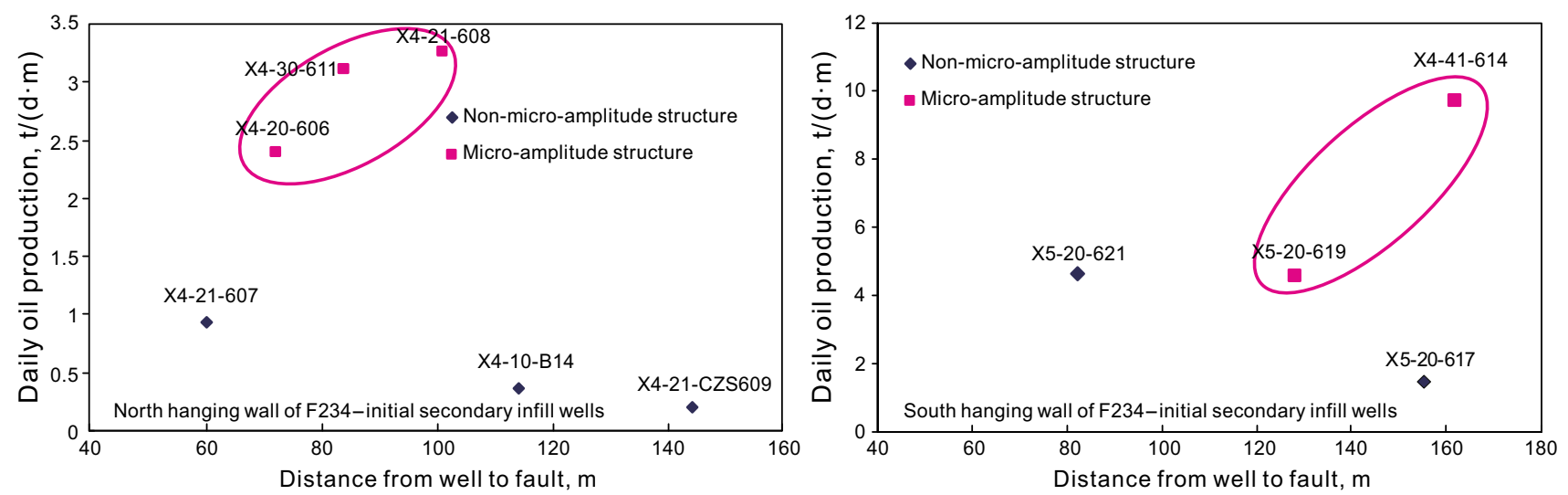

Fig. 7 Remaining oil distribution in and out of the micro-amplitude structure from oil production data

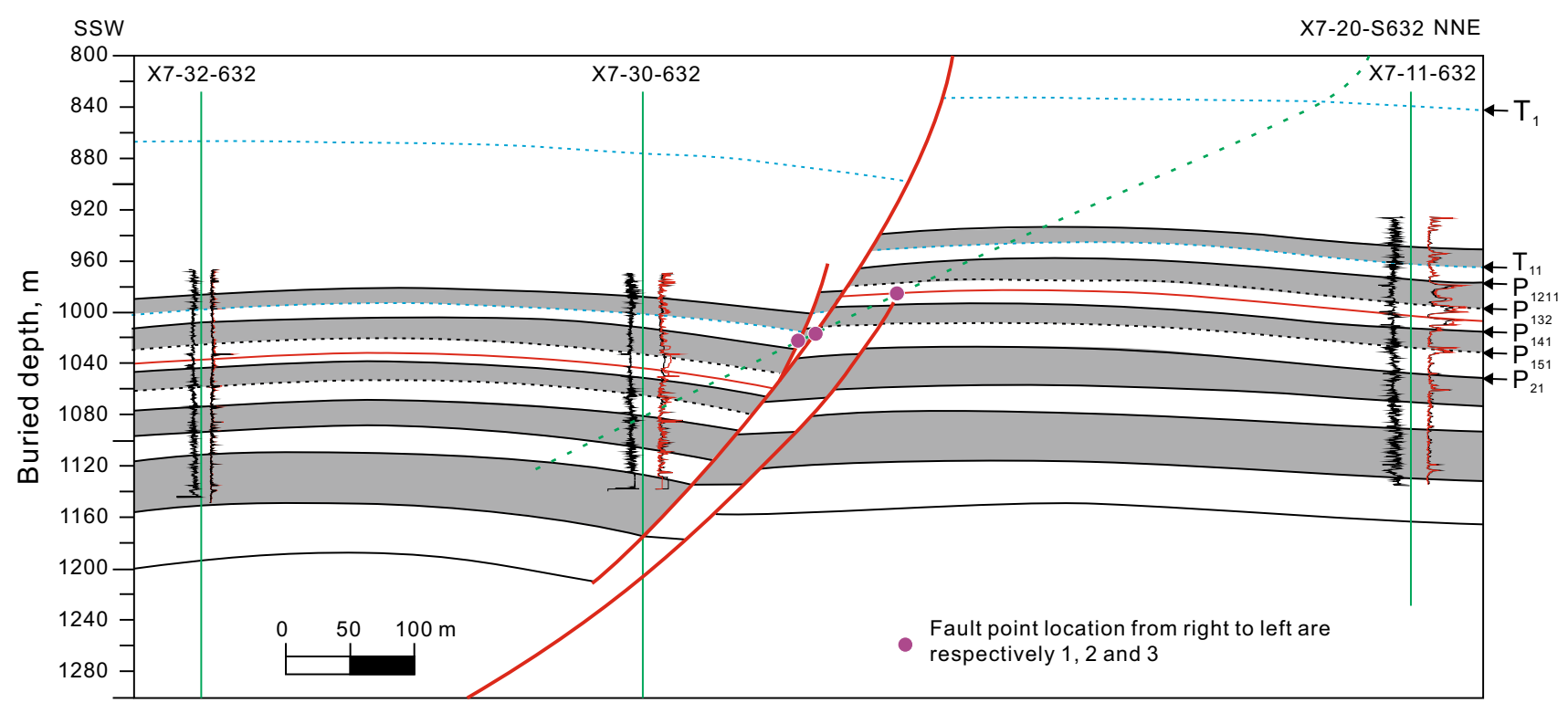

Fig. 8 Well trajectory and No. 275 fault point of X7-20-X632

Fossen and Bale 2007). In order to perform a detailed analysis on the internal structure of a fault zone in underground geological conditions, the Xing 7-20-X632 (Fig. 8) directional well was drilled across the fault in the hanging wall of Fault 275, and cores were recovered systematically near the fault zone. The three fault points were drilled in Well Xing 7-20-X632, of which the first $(1272.15 \mathrm{~m})$, located in sandstone, is a damage zone at the fault termination, with the typical internal structure of cataclastic fault zones (Aydin and Johnson 1978; Hesthammer et al. 2000; Hesthammer and Fossen 2001; Mair et al. 2000; Fossen and Bale 2007). Slip surfaces and clustered deformation zones developed in the fault core, with a clustered cataclastic zone developed in pure sandstone (with shale content less than $15 \%$ ), and clustered and layered silicateframe fault rocks developed in impure sandstone (with shale content more than $15 \%$ ) (Knipe 1992, 1997; Knipe et al. 1997). The macroscopic and microscopic observations of the internal structure of fault zones show that a great amount of deformation developed in the damage zone, which is characterized by a rib convex shape with its color darker than the parent rock under the microscope. Cataclastic zones are characterized by reduced particle size, poor sorting, and pores in the cataclastic zone that are filled by detrital material and appear argillaceous under the microscope (Fig. 9). As the distance from the slip surface to parent rock becomes smaller, the density of the deformation zone becomes higher and higher (Fig. 10), and the width of damage zone is approximately $4.5 \mathrm{~m}$. The overall plane porosity ratio is about the sum of the effective pore area ratio and the residual oil area ratio. Research on the microstructural characteristics of damage zones indicates 

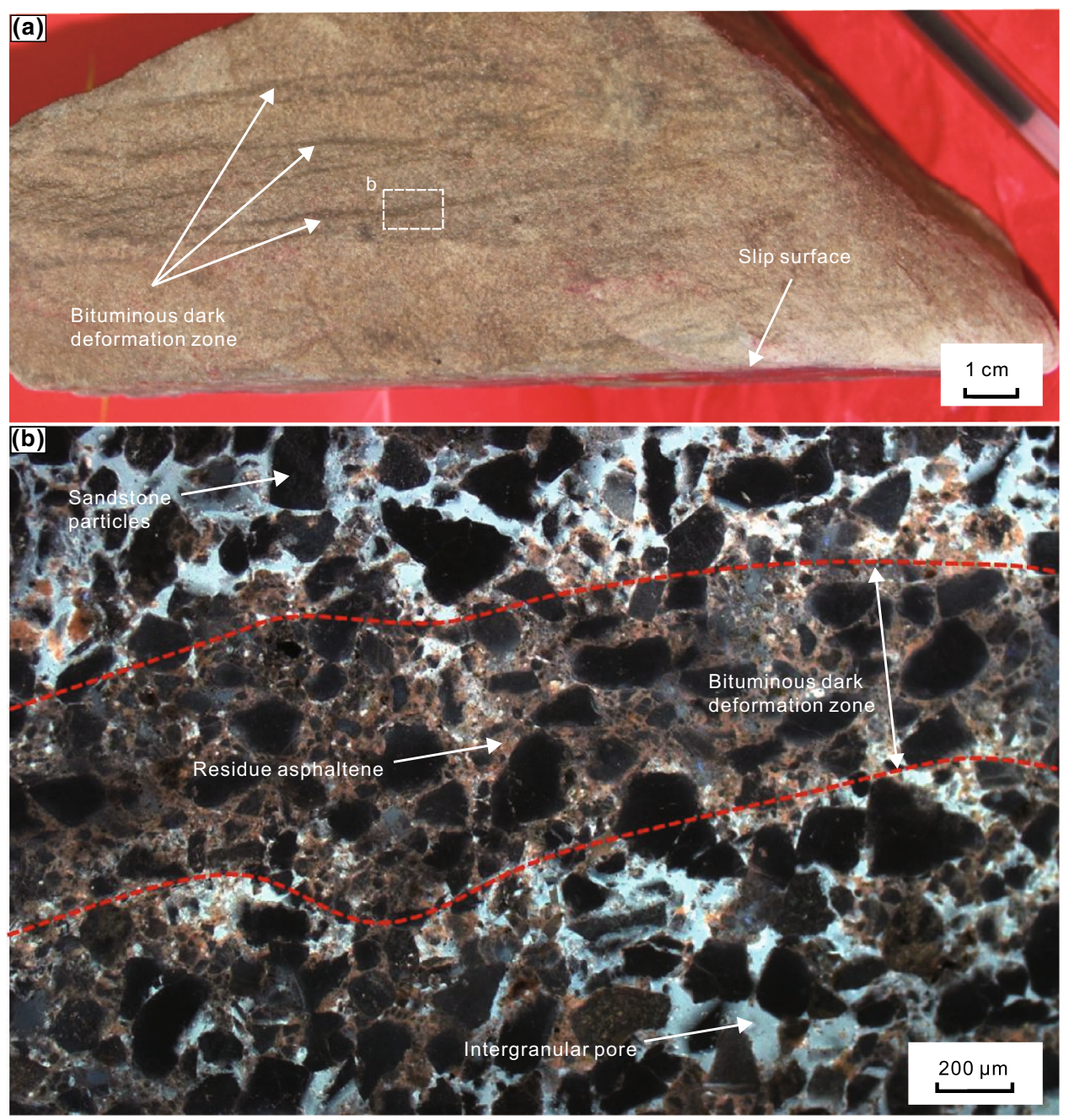

Fig. 9 Macroscopic and microscopic characteristics of the internal structure of the fault zone

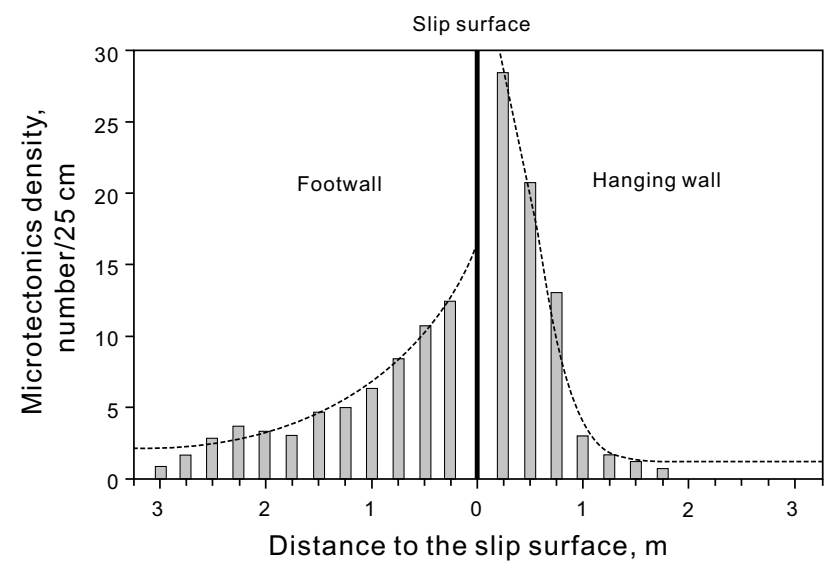

Fig. 10 Deformation band density change away from the slip surface of No. 1 fault point

(Fig. 11) that the total plane porosity ratio of the cataclastic deformation zone is $13.2 \%$, the effective plane porosity ratio is $1.5 \%$, and the oil area ratio is $11.7 \%$. The total plane porosity ratio of the surrounding (parent) rock is $23.3 \%$, the effective plane porosity ratio of the surrounding (parent) rock is $20.9 \%$, and the oil area ratio is $2.4 \%$. The results show that the deformation zone has lower porosity and permeability than the parent rocks.

\subsection{Control of fault sealing properties on remaining oil distribution}

The oil-bearing layer of the first member of the Yaojia Formation is a typical interbedded sand-mud reservoir. Fault sealing ability mainly relies on clay content filled in the fault zone. It is a typical fault rock seal (Fu et al. 2010). Based on the quantitative relationship between the shale gouge ratio (SGR) of fault rock and the height of hydrocarbon column [Eqs. (1) and (2)], we confirm that the critical fault sealing SGR value is $30 \%$ (Fig. 12). Most of the reservoirs controlled by faults where the SGR is higher than $30 \%$ are oil layers, i.e., faults are sealing ones. At the 

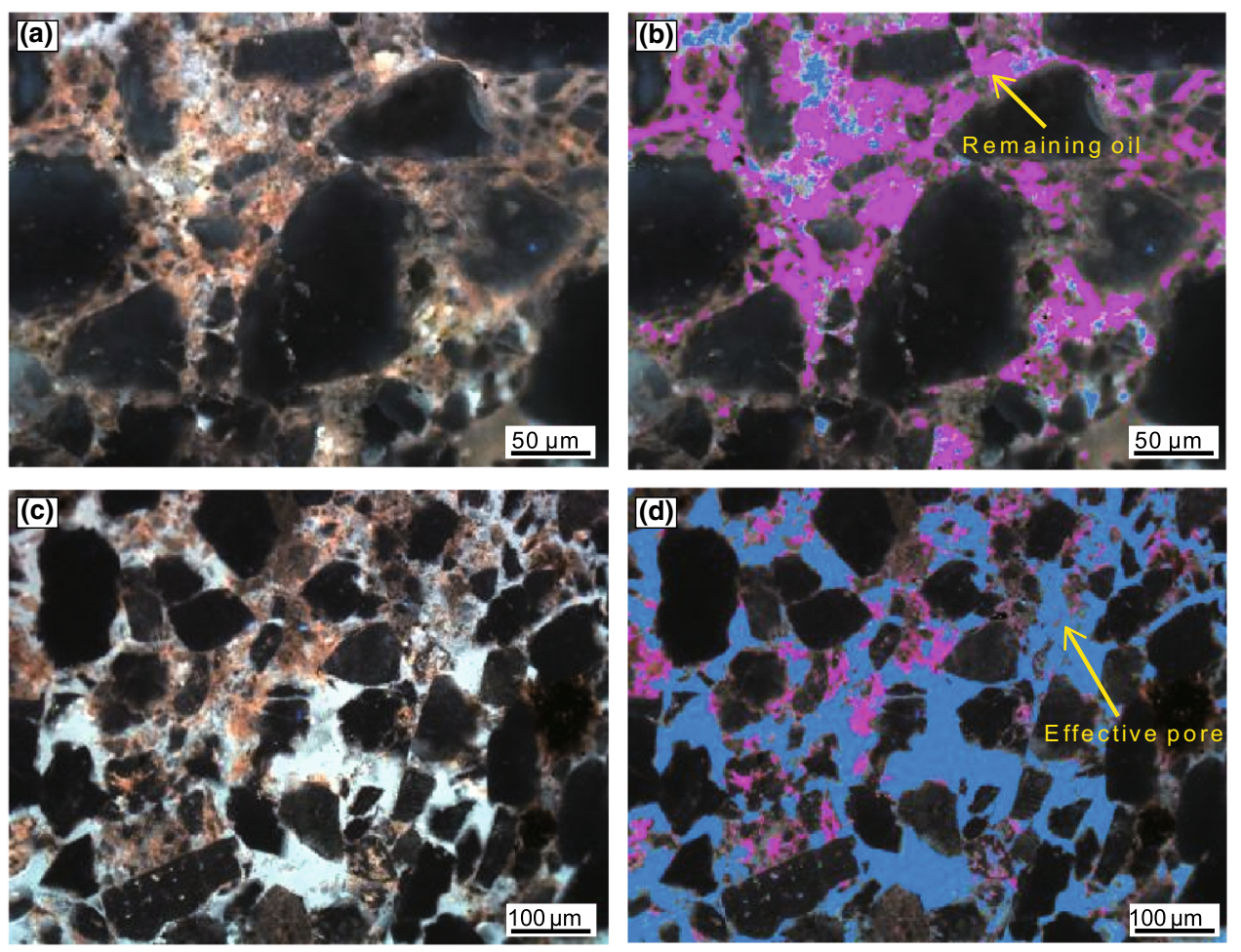

Fig. 11 Photomicrographs showing porosity and remaining oil distribution of the deformation zone and the surrounding rock. a Micro-scale characteristics of the deformation zone. b Micro-scale characteristics of the deformation zone by fluorometric analysis.

c Micro-scale characteristics of the surrounding rock. d Micro-scale characteristics of the surrounding rock by fluorometric analysis

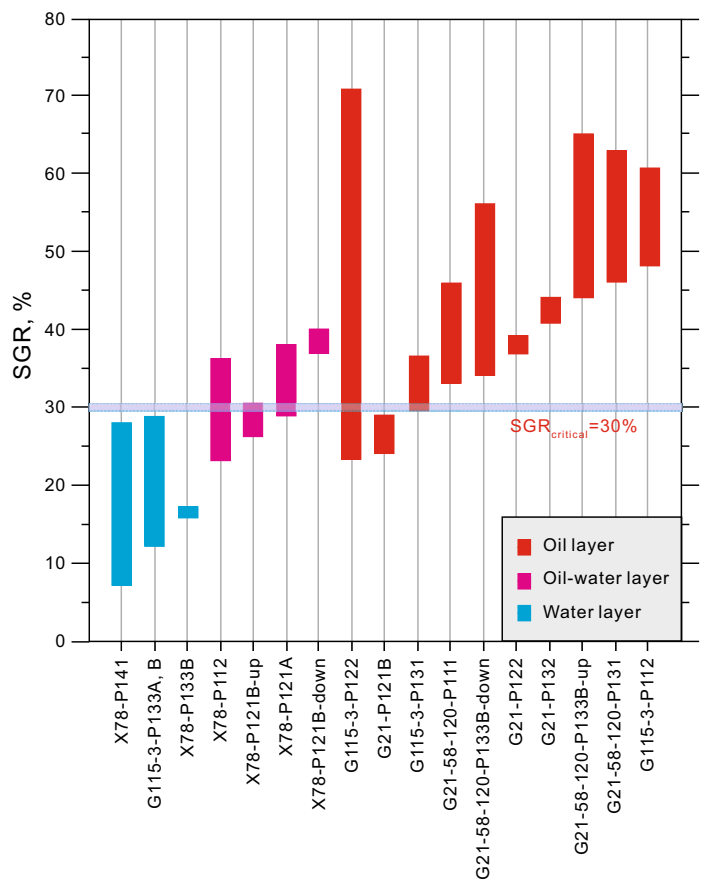

Fig. 12 Critical SGR (30\%) of fault sealing

position that SGR is lower than $30 \%$, most of the sand bodies controlled by faults are oil-water layers or water layers, i.e., faults have a higher leakage risk.
$P_{\text {fault }}=\left(\rho_{\mathrm{w}}-\rho_{\mathrm{o}}\right) g=10^{\left(\frac{\mathrm{SGR}}{45}-0.5\right)}$

$H=\frac{10^{\left(\frac{\mathrm{SGR}}{45}-0.5\right)}}{\left(\rho_{\mathrm{w}}-\rho_{\mathrm{o}}\right) g}$,

where $P_{\text {fault }}$ is the fault breakthrough pressure, $\mathrm{MPa}, \rho_{\mathrm{w}}$ is the water density, $\mathrm{kg} / \mathrm{m}^{3}, \rho_{\mathrm{o}}$ is the oil density, $\mathrm{kg} / \mathrm{m}^{3}, g$ is the acceleration of gravity, $\mathrm{m} / \mathrm{s}^{2}$, and $H$ is the oil column height, $\mathrm{m}$.

Taking Fault 234 as a detailed example (Fig. 13), the SGR of the fault surface, the breakthrough pressure, and the hydrocarbon column height are calculated. The minimum SGR occurs at the fault termination and the leakage risk is commensurately higher. The sealing ability of faults at the locations with larger throw is higher, and remaining oil is richer there.

\section{Prediction of remaining oil distribution at the fault edge}

\subsection{Types of remaining oil at the fault edge}

Based on the injection-production relationship at the fault edge, the remaining oil is classified into three types. The first oil type is the oil remaining after imperfect injection 

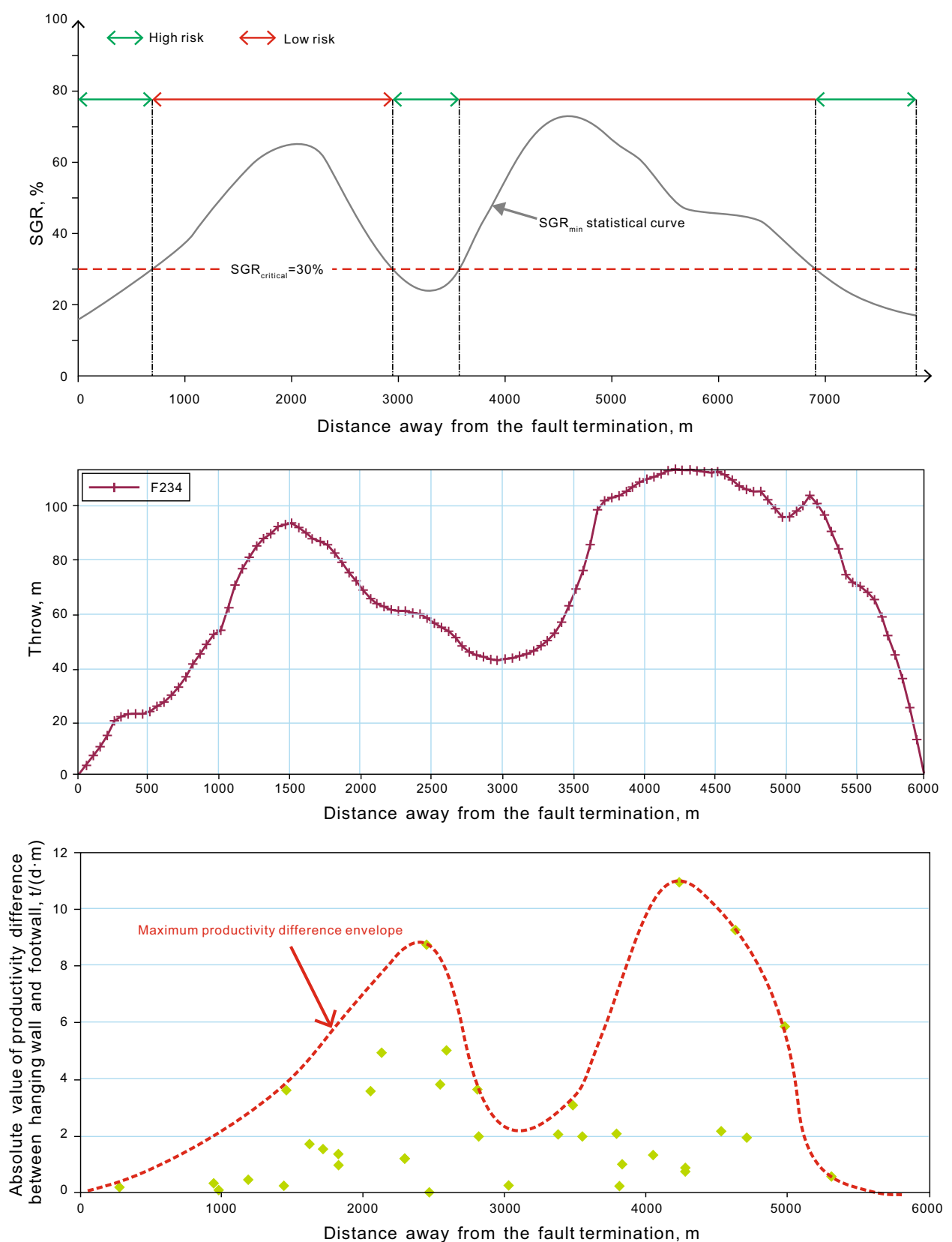

Fig. 13 Relation to fault seal and remaining oil distribution of No. 234 (productivity difference between hanging wall and footwall means the difference of oil production between hanging wall and footwall, which reflects the sealing capacity of fault)

and production. In some depositional time units, the matching of sand bodies and injection-production patterns is imperfect within some sand bodies. Some patterns in some localized areas have production without injection or have injection without production. As a result, remaining oil is due to imperfect injection and production. The effective thickness of sand bodies in $\mathrm{PuI}_{2}^{2}$ unit formation to the south of Fault 234 is $1.92 \mathrm{~m}$. Well Xing 5-2-21 and Well Xing 5-2-22 at the edge of Fault 234 have been perforated. However, oil wells Xing 5-21-619 and Xing 5-21-620 and water wells Xing 5-2-719 and Xing 5-2-122 outside the scope of well spacing have not been perforated, which belong to typical remaining oil types with injection but without production in individual sand bodies (Fig. 14a). The second type is oil remaining outside the controlling well pattern. Sand bodies in small underwater distributary channels are narrow and thin and have higher clay content and poorer physical properties and oiliness because of slightly lower river energy. However, narrow sand bodies lead to a low drilling rate, thus few wells or none have been drilled in the sand bodies within the range of hundreds of meters to several kilometers. However, 


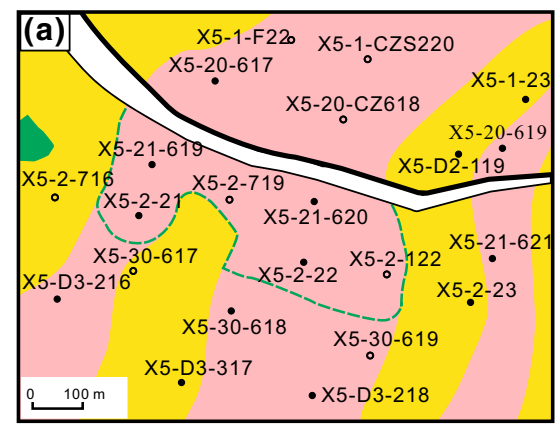

$\begin{array}{lll}\square & \text { Fault } & \bullet\end{array}$

Micro-amplitude structure range

Micro-amplitude structure type
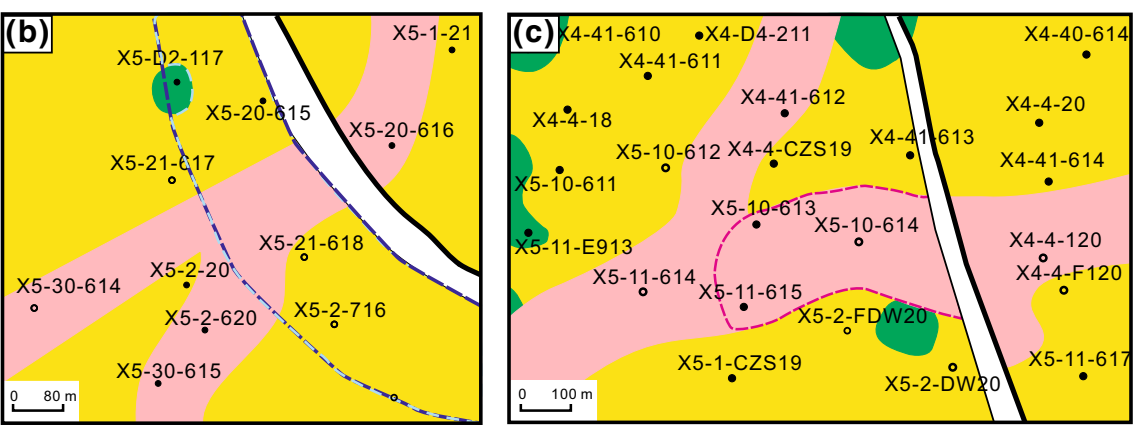

O Water well $\bigcirc$ Clay

Channel sand

Iே-ב Uncontrolled well pattern type

(匚ニ) Incomplete injection recovery type

Fig. 14 Remaining oil type in the vicinity of faults

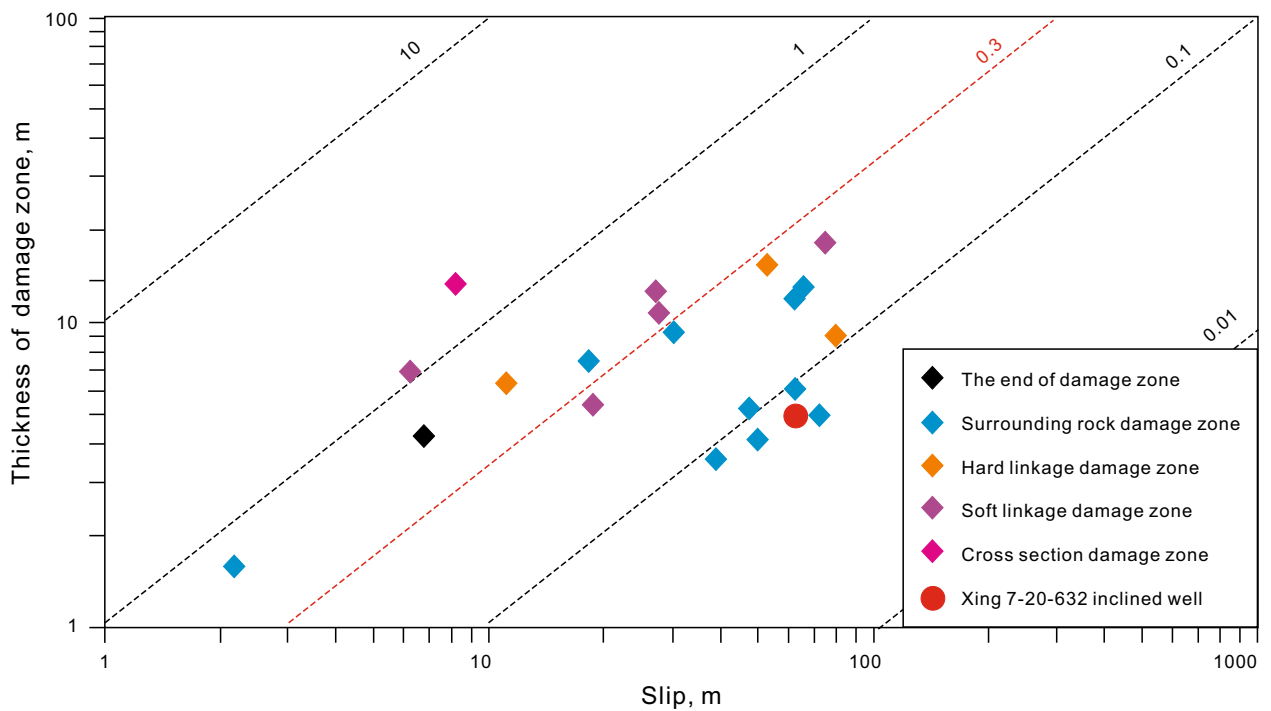

Fig. 15 Relation to throw and thickness of the damage zone
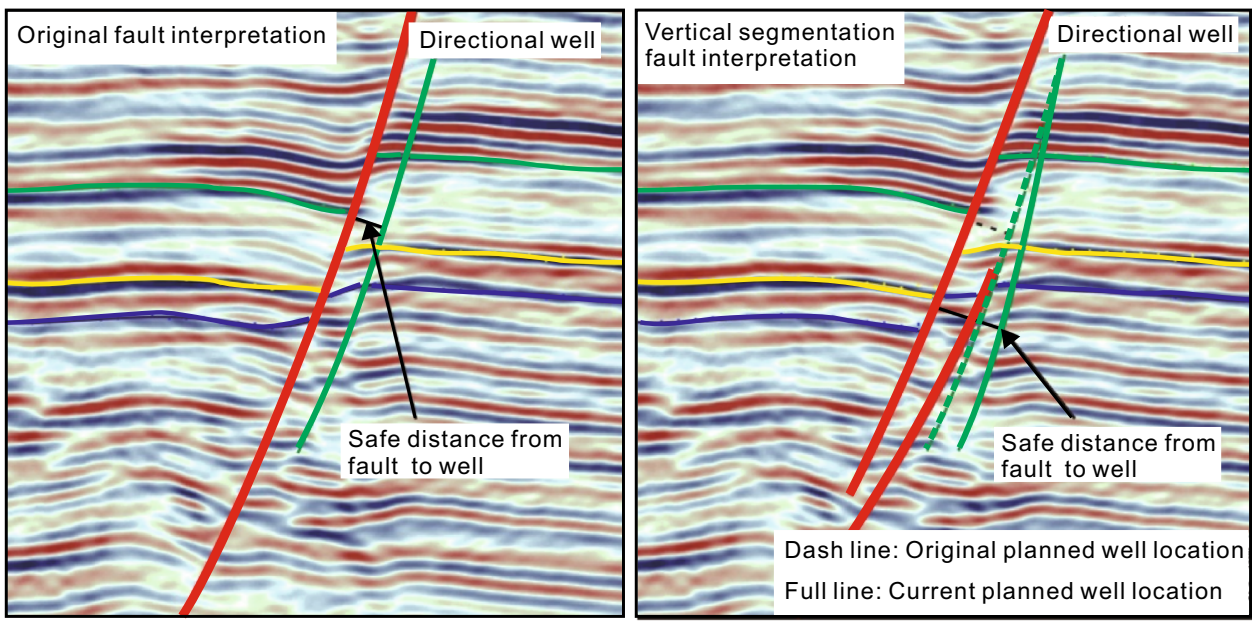

Fig. 16 Fault combination and safe distance from the high-angle well to the fault zone 
there are few oil production wells without water injection or few water injection wells without oil production, so oil layers are not produced or produced with lower degree, seriously influencing the producing degree and productivity of oil layers. That amounts to no water injection in the oil layer, resulting in oil remaining outside the controlling well pattern. Sand bodies at the $\mathrm{SaII}_{5}^{1}$ unit formation in central Fault 234 have an area of $0.116 \mathrm{~km}^{2}$ and an effective thickness of $0.8 \mathrm{~m}$. There exists a small but thick channel sand at the fault edge. Because the three wells within the channel sand are not perforated, remaining oil is rich here (Fig. 14b). The third type is the oil remaining within micro-amplitude structures. At the fault edge, small anticlines come from structural deformation. When sand bodies developed, oil remains, i.e., remaining oil of microamplitude structures. Sand bodies at the $\mathrm{SaII}_{8}$ unit formation to the south of Fault 234 have an effective thickness of $1.04 \mathrm{~m}$ and are located in micro-amplitude structures. Well Xing 5-2-20 has been perforated outside the micro-amplitude structural trap, yet Well Xing 5-20-615, Well Xing 5-21-618, and Well Xing 5-2-716 at higher position in the structures have not been perforated. Therefore, it is confirmed that remaining oil is controlled by micro-amplitude structures in the trap (Fig. 14c).

\subsection{Prediction of distribution and potential tapping methods of remaining oil at fault edges}

On the basis of fault zone structures and their control on remaining oil distribution, and the types of remaining oil, a three-step approach for predicting distribution of remaining oil at fault edges was developed. First, we should determine faults and fault blocks with rich remaining oil and optimal NNW antithetic fault footwalls based on the matching relationship between faults and reservoirs. Second, we will determine the location of faults by superposing micro-amplitude structures, ranges of fault sealing oil, and the oblique anticlines formed by soft-linkage faults, and determining favorable locations for the distribution of remaining oil. Third, we should determine the horizon for tapping remaining oil potential in favorable settings on the basis of the injection-production relationships of all sublayers.

Remaining oil at fault edges is mainly tapped by multitarget directional wells. Rational well spacing (distance from fault to well) is determined, according to fault combination modes and widths of damage zones. Two issues have to be taken into account for safe remaining oil production. First is the width of damage zone. Owing to the strong heterogeneity of the reservoir in the damage zone, the porosity of the damage zone drops considerably, and the permeability declines by $2-3$ orders of magnitude. This is unfavorable for efficient oil and gas development.
Meanwhile, casing damage or water injection leakage often occurs when drilling in the damage zone. So directional well deployment should keep away from the damage zone. Well coring and logging data show that the width of damage zone on the side of fault core is less than $15 \mathrm{~m}$ in general (Fig. 15), so the distance from well to fault should be larger than $15 \mathrm{~m}$. The other issue is that safe remaining oil production at fault edges ignores an important geologic phenomenon-vertically segmented growth of faults (Rykkelid and Fossen 2002; Sperrevik et al. 2000; Færseth 2006). So a fault that is traditionally interpreted as a single through-going fault may be composed of two vertically en echelon overlying faults, and the separation between en echelon overlying faults has to be considered (Fig. 16). The safe distance of remaining oil well deployment at fault edges is the sum of the width of damage zone and the separation between vertically segmented growth faults.

\section{Conclusions}

(1) The greater the fault throw, the richer the remaining oil, which is controlled by two factors. One is that the oil layer at the first member of the Yaojia Formation tends to be juxtaposed against a top mudstone, so the sealing capacity of faults becomes stronger with increased fault throw. The other is that due to differential subsidence, areas with greater throw of antithetic faults and nearer to the structural high spot are more conducive to the enrichment of remaining oil.

(2) There are two major types of positive microamplitude structures developed at the fault edge: the first is tilted fault blocks controlled by the footwall of antithetic faults, and the second is the lateral anticlines at the hanging wall controlled by synthetic fault linkage points. Based on the principle of differential fault subsidence, a preliminary method is established to predict micro-amplitude structures using a throw-distance curve.

(3) The macroscopic and microscopic observation of the well cores of the first cross fault in the Songliao Basin confirmed that fault deformation is cataclastic, forming typical internal structures of cataclastic fault zones. Slip surfaces and clustered deformation zones are developed in the fault core. The density of the deformation zone becomes more and more closer to the slip plane. The deformation zone has lower porosity and permeability than the surrounding rock, and remaining oil in the damage zone concentrates in the deformation zone.

(4) Based on the quantitative relationship between the SGR of fault rocks and the height of the hydrocarbon 
column, the critical SGR of the sealed fault in the first member of the Yaojia Formation of the Xingshugang structural zone is $30 \%$. In addition, the sealing ability of faults with larger fault throw is stronger, and remaining oil there is relatively richer.

(5) On the basis of the internal structure of fault zones, and its control on remaining oil and the type of remaining oil, a method is established that predicts the distribution of remaining oil. Two factors have to be taken into account for safe remaining oil well deployment distance at fault edges. These are the width of the damage zone and the separation of vertically segmented growth faults.

Acknowledgments The authors greatly appreciate the financial support from the Natural Science Foundation of China (Grant No. 41272151, 41472126), the Natural Science Foundation for Distinguished Young Scholars of Heilongjiang Province, China (Grant No. JC201304), the Joint Funds of the National Natural Science Foundation of China (Grant No. U1562214), and the Program for Huabei Oilfield (Grant No. HBYT-CY5-2015-JS-127).

Open Access This article is distributed under the terms of the Creative Commons Attribution 4.0 International License (http://crea tivecommons.org/licenses/by/4.0/), which permits unrestricted use, distribution, and reproduction in any medium, provided you give appropriate credit to the original author(s) and the source, provide a link to the Creative Commons license, and indicate if changes were made.

\section{References}

Aydin A, Johnson AM. Development of faults as zones of deformation bands and as slip surfaces in sandstone. Pure appl Geophys. 1978;116(4-5):931-42.

Bretan P, Yielding G, Jones H. Using calibrated shale gouge ratio to estimate hydrocarbon column heights. AAPG Bull. 2003;87(3):397-413.

Caine JS, Evans JP, Forster CB. Fault zone architecture and permeability structure. Geology. 1996;24(11):1025-8.

Cloos H. Über antithetische Bewegungen. Geol Rundsch. 1928;19(3):246-51.

Færseth RB. Shale smear along large faults: continuity of smear and the fault seal capacity. J Geol Soc. 2006;163(5):741-51.

Feng CJ, Bao ZD, Yang L, et al. Reservoir architecture and remaining oil distribution of deltaic front underwater distributary channel. Pet Explor Dev. 2014;41(4):323-9 (in Chinese).

Fossen H. Structural geology. New York: Cambridge University Press; 2010. p. 152-85.

Fossen H, Bale A. Deformation bands and their influence on fluid flow. AAPG Bull. 2007;91(12):1685-700.

Fossen H, Schultz RA, Shipton ZK, et al. Deformation bands in sandstone: a review. J Geol Soc. 2007;164(4):755-69.

Fu XF, Li WL, Lv YF, et al. Quantitative estimation of lateral fault seal and application in hydrocarbon exploration. Geol Rev. 2011;57(3):387-97 (in Chinese).

Fu XF, Sha W, Yu D, et al. Lateral sealing of faults and gas reservoir formation in volcanic rocks in Xujiaweizi fault depression. Geol Rev. 2010;56(1):60-70 (in Chinese).
Gao MX. Tracing seismotectonic activity tendency-a possible approach for practical earthquake prediction. Recent Dev World Seismol. 1983;9:00 (in Chinese).

Gao RQ. Characteristics of the continental Cretaceous in the Songliao Basin. Acta Geol Sin. 1980;54(1):9-26 (in Chinese)

Gao RQ, Cai XY. Formation conditions and distribution of oil and gas fields in the Songliao Basin. Beijing: Petroleum Industry Press; 1997. p. 12-40.

Giba M, Walsh JJ, Nicol A. Segmentation and growth of an obliquely reactivated normal fault. J Struct Geol. 2012;39(2):253-67.

Han DK. Status and challenges for oil and gas field development in China and directions for the development of corresponding technologies. Eng Sci. 2010;12(5):51-7 (in Chinese).

Hesthammer J, Fossen H. Structural core analysis from the Gullfaks area, northern North Sea. Mar Pet Geol. 2001;18(3):411-39.

Hesthammer J, Johansen TES, Watts L. Spatial relationships within fault damage zones in sandstone. Mar Pet Geol. 2000;17(8):873-93.

Hills ES. Outlines of structural geology. London: Methuen; 1953. p. 22-36.

Hou J, Luo FQ, Li ZQ, et al. The critical description scale study on core microscopic and reservoir macroscopic remaining oil. Pet Geol Recovery Effic. 2014;21(6):95-8 (in Chinese).

$\mathrm{Hu}$ WR. Necessity and feasibility of PetroChina mature field redevelopment. Pet Explor Dev. 2008;35(1):1-5 (in Chinese).

$\mathrm{Hu}$ WS, Wang JL. Extensional tectonic evolution and petroleum accumulation in Songliao Basin. Pet Explor Dev. 1996;23(3):30-3 (in Chinese).

Jiang YL. Water-control and energy-saving \& trapping potential test inside layer for La 9-232 well block. Energy Conserv Pet Petrochem Ind. 2013;7:9-11 (in Chinese).

Jin Q, Wang RP, He RW, et al. Identification and description of small faulted-block reservoirs. Acta Pet Sin. 2009;30(3):367-71 (in Chinese).

Jin Q, Zhou JF, Wang DP, et al. Identification of shattered fault zones and its application in development of fault-block oilfields. Acta Pet Sin. 2012;33(1):82-9 (in Chinese).

Kim YS, Sanderson DJ. The relation between displacement and length of faults. Earth Sci Rev. 2005;68(3):317-34.

Knipe RJ. Faulting processes and fault seal. Struct Tecton Model Appl Pet Geol. 1992;1:325-42.

Knipe RJ. Juxtaposition and seal diagrams to help analyze fault seals in hydrocarbon reservoirs. AAPG Bull. 1997;81(2):187-95.

Knipe RJ, Fisher QJ, Jones G, et al. Fault seal analysis: successful methodologies, application and future directions. Nor Pet Soc Spec Publ. 1997;7:15-38.

Liu Z, Lv YF, Sun YH, et al. Characteristics and significance of syngenetic fault segmentation in hydrocarbon accumulation: an example of Yuanyanggou fault in western sag, Liaohe Depression. J China Univ Min Technol. 2012;41(5):793-9 (in Chinese).

Liu ZB. High resolution sequence stratigraphy and hydrocarbon accumulation model of Fuyu reservoir in Sanzhao Depression. Ph.D. Thesis, Northeast Pet University. 2010 (in Chinese).

Liu ZB, Ma SZ, Sun Y, et al. High-resolution sequence stratigraphy division and depositional characteristics of Putaohua reservoir, Sanzhao Depression. Acta Sedimentol Sin. 2008;26(3):399-406 (in Chinese).

Liu ZB, Yan L, Gao F, et al. Enrichment rule and tapping methods of remaining oil on fault boundary at high water cut stage oil-fields: a case of Putaohua reservoir of the north fault block of Xingnan oilfield, Songliao Basin. J Northeast Pet Univ. 2014;38(4):52-8 (in Chinese).

Liu ZC. Improving oil recovery technology applications and development directions in Sinopec. Sinopec. 2008;4:5-8 (in Chinese). 
Mair K, Main I, Elphick S. Sequential growth of deformation bands in the laboratory. J Struct Geol. 2000;22(1):25-42.

Miall AD. Reconstructing fluvial macroform architecture from twodimensional outcrops: examples from the Castlegate Sandstone, Book Cliffs, Utah. J Sediment Res. 1994;64(2):146-58.

Peacock DCP. Displacement and segment linkage in strike-slip fault zones. J Struct Geol. 1991;13(9):1025-35.

Peacock DCP, Sanderson DJ. Displacements, segment linkage and relay ramps in normal fault zones. $\mathrm{J}$ Struct Geol. 1991;13(6):721-33.

Peacock DCP, Sanderson DJ. Geometry and development of relay ramps in normal fault systems. AAPG Bull. 1994;78(2):147-65.

Peacock DCP, Knipe RJ, Sanderson DJ. Glossary of normal faults. J Struct Geol. 2000;22(3):291-305.

Peng SM, Zhou HT, Li HY, et al. Phased flow unit model establishment and remaining oil prediction: An example from Jing 11 block in Bieguzhuang Oilfield. Pet Explor Dev. 2007;34(2):216-21 (in Chinese).

Qi JF. Two tectonic systems in the Cenozoic Bohai Bay Basin and their genetic interpretation. Geol China. 2004;31(1):15-22 (in Chinese)

Rykkelid E, Fossen H. Layer rotation around vertical fault overlap zones: observations from seismic data, field examples, and physical experiments. Mar Pet Geol. 2002;19(2):181-92.

Soliva R, Benedicto A. A linkage criterion for segmented normal faults. J Struct Geol. 2004;26(12):2251-67.

Soliva R, Benedicto A, Schultz RA, et al. Displacement and interaction of normal fault segments branched at depth: Implications for fault growth and potential earthquake rupture size. J Struct Geol. 2008;30(10):1288-99.
Sperrevik S, Færseth RB, Gabrielsen RH. Experiments on clay smear formation along faults. Pet Geosci. 2000;6(2):113-23.

Sun YH, Chen YB, Sun JG, et al. Evolutionary sequence of faults and the formation of inversion structural belts in the northern Songliao Basin. Pet Explor Dev. 2013;40(3):275-83 (in Chinese).

Wang HX, Li MH, Shen ZS, et al. The establishment and geological significance of quantitative discrimination criterion of fault segmentation growth: an example from Saertu reservoir in Xingbei development area of Songliao Basin. Geol Rev. 2014;60(6): 1259-64 (in Chinese).

Wang HX, Lv YF, Fu XF, et al. Formation, evolution and reservoircontrolling mechanism of relay zone in rift basin. Geol Sci Technol Inf. 2013;34(4):102-10 (in Chinese).

Yielding G. Shale gouge ratio: calibration by geohistory. Norwegian Pet Soc Spec Publ. 2002;11(2):1-15.

$\mathrm{Yu}$ SD. The development models of complicated fault-block sandstone oilfield. Beijing: Petroleum Industry Press; 1998. p. 1-35 (in Chinese).

Yue DL, Wu SH, Cheng HM, et al. Numerical reservoir simulation and remaining oil distribution patterns based on 3D reservoir architecture model. J China Univ Pet. 2008;32(2):21-7 (in Chinese).

Yun JB, Jin ZJ, Yin JY. Characteristics of inherited fault belts and their effect on hydrocarbon accumulation. Geotecton Metallog. 2002;26(4):379-85 (in Chinese).

Zhang GC, Xu H, Liu HF, et al. Inversion structures in relation to oil and gas field distribution in Songliao Basin. Acta Pet Sin. 1996;17(2):9-14 (in Chinese). 